\title{
Pengaruh Profil Leukosit dan Eritrosit Sapi Bali Jantan yang Digemukkan dengan Complete Feed yang Mengandung Level Protein Kasar Berbeda
}

\author{
Yulius Luan Halek ${ }^{\mathrm{a}}$, Paulus Klau Tahuk ${ }^{\mathrm{b}}$, Gerson Frans Bira ${ }^{\mathrm{c}}$ \\ ${ }^{a}$ Fakultas Pertanian, Universitas Timor, Kefamenanu, TTU - NTT, Indonesia, email: luanyulius@ gmail.com \\ ${ }^{b}$ Fakultas Pertanian, Universitas Timor, Kefamenanu, TTU - NTT, Indonesia, email: paulklau@ @ahoo.co.id
}

${ }^{c}$ Fakultas Pertanian, Universitas Timor, Kefamenanu, TTU - NTT, Indonesia, email: gersonbira@ yahoo.co.id

\section{Article Info}

\section{Article history:}

Received 11 Agustus 2020

Accepted 15 Januari 202

DOI:

https://doi.org/10.32938/ja.v6i1.1093

\section{Keywords:}

Leukosit dan eritrosit

Level protein kasar

Pakan komplit

Sapi Bali jantan penggemukan
Received in revised form 30 Oktober 2020

\section{Abstrak}

Tujuan dari penelitian ini adalah untuk mengetahui profil leukosit dan eritrosit sapi bali jantan yang digemukkan dengan complete feed yang mengandung level protein kasar (PK) berbeda. Ternak yang digunakan berupa sapi bali jantan berumur 2-2,5 tahun dengan berat awal $200 \mathrm{~kg}$. Ransum yang digunakan adalah complete feed yang tersusun dari bahan pakan berupa rumput alam, tepung gamal, dedak padi, jagung giling, danbran pollard. Variabel yang diukur dalam penelitian adalah kandungan leukosit dan eritrosit. Metode yang digunakan adalah metode eksperimen menggunakan rancangan acak lengkap (RAL) dengan perlakuan sebagai berikut: $\mathrm{T}_{1}$ : Tepung Rumput $27 \%$ + Tepung Gamal 10\% + Jagung 34\% + Pollard 15\% + Dedak Padi 14\%, $\mathrm{T}_{2}$ : Tepung Rumput 27\% + Tepung Gamal 20\% + Jagung 18\% + Pollard 15\% + Dedak Padi 10\%,dan $\mathrm{T}_{3}$ : Tepung Rumput 27\% + Tepung Gamal 13\% + Jagung 20\% + Pollard $15 \%+$ Dedak Padi 7\%. Hasil penelitian menunjukkan bahwa, penggunaan complete feed dengan level PK yang berbeda tidak berpengaruh terhadap kandungan eritrosit dan leukosit sapi bali jantan. Hal ini ditunjukkan oleh kandungan eritrosit (10\% $/ \mu$ I) setiap perlakuan, yaitu T1: 11,08; T2: 10,30; T3: 10,99; kandungan leukosit $\left(10^{3} / \mu \mathrm{I}\right)$ masing-masing perlakuan adalah T1: 10,51; T2: 11,59; T3: 10,48. Disimpulkan bahwa pemberian complete feed dengan level PK $(11 \%, 13 \%, 15 \%)$ dan energi (TDN $72 \%)$ memberikan pengaruh yang sama untuk semua perlakuan dan menghasilkan kandungan eritrosit dan leukosit dalam kisaran normal.

\section{Pendahuluan}

Sapi bali adalah sapi lokal yang mempunyai daya kemampuan adaptasi yang cukup baik dengan lingkungan. Kemampuan tersebut merupakan salah satu faktor pendukung keberhasilan budi daya ternak sapi (Nurhannah, 2014). Provinsi Nusa Tenggara Timur (NTT) merupakan salah satu daerah penghasil ternak Sapi Bali. Hal ini terlihat dari meningkatnya populasi sapi potong di provinsi NTT; dimana pada tahun 2016 sebesar 984.508 ekor, mengalami peningkatan 4,06\% pada tahun 2017 menjadi 1.007.608 ekor (Ditjen PKH, 2017). Peningkatan populasi ternak sapi potong di NTT tidak terlepas dari keunggulan sapi bali yang cukup adaptif terhadap kondisi lingkungan ekstrim, serta potensi alam yang menunjang perkembangan sektor peternakan; seperti padang penggembalaan alam yang cukup luas, mencapai 546.766,90 ha (BPS NTT, 2017)

Pada umumnya NTT, terdiri dari dua musim yaitu musim hujan (basah) berlangsung selama 4 bulan dan musim kemarau berlangsung selama 8 bulan. Pada musim hujan, hijauan makanan ternak melimpah sehingga pertumbuhan ternak cukup stabil dan cenderung meningkat, sedangkan pada musim kemarau ketersediaan pakan hijauan sangat kurang dan kualitasnya rendah sehingga berpengaruh terhadap penurunan produktivitas ternak seperti kematian pedet penurunan bobot badan, pertumbuhan lambat, dan penurunan reproduks (Tahuk dan Dethan, 2010)

Solusi untuk mengatasi kekurangan pakan ternak pada musim kemarau adalah dengan pemanfaatan kelimpahan hijauan makanan ternak pada musim hujan seperti rumput lapangan dan gamal yang masih tersedia di lapangan. Bahan pakan tersebut dapat diolah sebagai pakan komplit untuk mengatas kekurangan pakan pada musim kemarau sehingga produktivitas ternak tetap terjamin. Pakan komplit merupakan pakan yang cukup mengandung nutrien untuk ternak dalam tingkat fisiologis tertentu yang dibentuk dan diberikan sebagai satu-satunya pakan yang mampu memenuhi kebutuhan hidup pokok dan produksi tanpa tambahan substansi lain kecuali air. Semua bahan pakan tersebut; baik pakan kasar maupun konsentrat, dicampur secara homogen menjadi satu.

Pada pemeliharaan ternak, protein yang diperoleh ternak akan berdampak pada peningkatan profil leukosit dan eritrosit, dimana masing masing komponen darah tersebut akan berdampak terhadap peningkatan produktivitas ternak (Mide, 2011). Pemanfaatan pakan ternak sapi bali dapat dilihat dari penyerapan nutrisi pakan yang dikonsumsi. Pakan yang dikonsums akan dicerna dan didegradasi dalam bentuk nutrien yang kemudian diserap ke dalam darah untuk dialirkan ke seluruh tubuh dengan tujuan mempertahankan keutuhan fungsi organ tubuh.

Darah mempunyai unsur seluler, terdiri atas eritrosit (sel-sel darah merah), leukosit (sel-sel darah putih) dan trombosit (keping darah). Pemeriksaan eritrosit dilakukan untuk mengetahui keadaan anemia dan polisitemia. Leukosit merupakan unit yang aktif dari sistem pertahanan tubuh, yang sebagian dibentuk di sumsum tulang (granulosit dan monosit serta sediki limfosit) dan sebagian lagi di jaringan limfa (limfosit dan sel-sel plasma) Setelah dibentuk, sel-sel ini diangkut dalam darah menuju berbagai bagian tubuh untuk digunakan sebagai pertahanan tubuh melawan benda asing yang masuk ke dalam tubuh. Menurut Fitria dan Sarto (2014), darah menjadi salah satu parameter pokok dalam penelitian pra klinik/biomedik.

Secara umum, total leukosit dan diferensial leukosit dapat memberikan gambaran dan status kesehatan pada hewan (Sugiharto, 2014). Isroli et al. (2009) menyatakan bahwa untuk mengetahui tingkat kekebalan tubuh dapat dilihat dari variabel darah berupa leukosit dan diferensial leukosit secara lengkap. Menurut Junqueira (1977), leukosit merupakan sel yang berperan dalam sistem pertahanan tubuh yang sangat tanggap terhadap agen infeksi penyakit. Leukosit berfungsi melindungi tubuh terhadap berbagai penyaki dengan cara fagosit dan menghasilkan antibodi. Pemberian pakan komplit diharapkan akan meningkatkan dan mempertahankan leukosit dan eritrosit agar pertumbuhan sapi bali penggemukkan menjadi efektif.

\section{Metode}

\subsection{Waktu dan Tempat Penelitian}

Penelitian ini telah dilaksanakan pada tanggal 14 Mei sampai 14 Agustus 2019 di kandang Fakultas Pertanian Universitas Timor. Analisis sampel darah dilakukan di Laboratorium Bio Reproduksi dan Kesehatan Ternak, Fakultas Peternakan, Universitas Nusa Cendana, Kupang.

\subsection{Materi Penelitian}

Ternak yang digunakan dalam penelitian ini adalah sapi bali jantan berumur 2-2,5 tahun berjumlah 12 ekor dengan berat badan awal $200 \mathrm{~kg}$. Alat yang digunakan adalah mesin giling, terpal, timbangan gantung kapasitas 40 $\mathrm{kg}$, timbangan digital, mikroskop, counting chamber, sentrifuse, tabung darah dengan lithium heparin (125.I.U) kapasitas $3 \mathrm{ml}$, parang, ember, dan timbangan sapi kapasitas 2 ton. Bahan yang digunakan dalam penelitian ini adalah rumput alam, daun gamal, tepung jagung, bran pollard, dedak padi, dan mineral. Kandang yang digunakan dalam penelitian ini berupa kandang individu model permanen yang terdiri dari 12 petak dengan ukuran tiap petak $200 \times 150 \mathrm{~cm}$, tinggi $200 \mathrm{~cm}$, serta tiap petak kandang dilengkapi dengan tempat pakan dan tempat minum.

\subsection{Metode Penelitian}

Metode penelitian yang digunakan dalam penelitian ini adalah Rancangan Acak Lengkap (RAL) yang terdiri dari 3 perlakuan dan 4 ulangan sehingga terdapat 12 unit percobaan. Perlakuan yang diberikan adalah sebagai berikut:

T1: Tepung Rumput 27\% + Tepung Gamal 10\% + Jagung 34\% + Pollard 15\% + Dedak Padi $14 \%$

T2: Tepung Rumput 27\% + Tepung Gamal 20\% + Jagung 18\% + Pollard 15\% + Dedak Padi $10 \%$

T3: Tepung Rumput 27\% + Tepung Gamal 13\% + Jagung 20\% + Pollard 15\% + Dedak Padi $7 \%$

Kandungan persentase $\mathrm{PK}$ dalam pakan komplit masing-masing perlakuan diantaranya: $\mathrm{T} 1=11 \%, \mathrm{~T} 2=13 \%$, dan $\mathrm{T} 3=15 \%$ dengan kandungan TDN $72 \%$. Hasil analisis kandungan nutrisi dari bahan penyusun pakan komplit

\subsection{Prosedur Penelitian}

Tahapan awal yang dilakukan adalah menyiapkan kandang, pembuatan pakan, serta pembuatan kandang dengan model permanen yang terdiri dari 12 petak kandang menggunakan papan kayu. Setelah pembuatan kandang, selanjutnya dilakukan pemotongan rumput alam, daun gamal, persiapan jagung, dan pollard, kemudian dibuat pakan komplit. Setelah pengambilan bahan pakan tersebut, kemudian dijemur sampai kering dan digiling menggunakan mesin pengiling. Gamal dan rumput yang sudah digiling kemudian dicampur dengan tepung jagung, serta dedak diberikan 2 kali dalam sehari yakni pagi dan sore hari sebanyak 3\% BK dari berat badan ternak. Air minum diberikan secara ad libitum menggunakan ember plastik yang diletakan di samping tempat makan.

Selanjutnya dilakukan prosedur pengambilan darah dimana darah diambil pada minggu terakhir penelitian melalui vena jugularis, menggunakan jarum serta tabung darah yang berisi lithium heparin ukuran $3 \mathrm{ml}$. Pengambilan darah sapi sebanyak 4 kali/ekor, dengan perbedaan waktu yaitu: 0 jam sebelum diberi makan (puasa), 2 jam, 4 jam, dan 6 jam setelah diberi makan. Darah yang ditampung pada tabung kemudian disimpan pada termos es, untuk selanjutnya dilakukan analisis darah di Laboratorium Bio Reproduksi dan Kesehatan Ternak, Fakultas Peternakan, Universitas Nusa Cendana, Kupang. dapat dilihat pada Tabel 1 
Tabel 1. Kandungan nutrisi bahan pakan penyusun pakan komplit.

\begin{tabular}{lccccc}
\hline \multicolumn{1}{c}{ Bahan Pakan } & $\begin{array}{c}\text { Rumput } \\
\text { Lapangan }\end{array}$ & $\begin{array}{c}\text { Daun } \\
\text { Gamal }\end{array}$ & $\begin{array}{c}\text { Jagung } \\
\text { Giling }\end{array}$ & $\begin{array}{c}\text { Bran } \\
\text { Pollard }\end{array}$ & $\begin{array}{c}\text { Dedak } \\
\text { Padi }\end{array}$ \\
\hline BK $(\%)$ & 88,986 & 85,260 & 85,950 & 87,165 & 89,691 \\
BO $(\%)$ & 77,388 & 76,397 & 83,012 & 82,663 & 77,062 \\
PK $(\%)$ & 5,318 & 21,377 & 9,609 & 16,648 & 10,444 \\
LK $(\%)$ & 0,805 & 3,403 & 8,967 & 3,329 & 8,181 \\
SK $(\%$ BK) & 28,221 & 11,137 & 3,059 & 6,902 & 15,103 \\
CHO $\%$ BK) & 71,266 & 51,617 & 64,437 & 62,685 & 58,436 \\
BETN $(\%$ BK) & 43,045 & 40,479 & 61,378 & 55,784 & 43,334 \\
GE & & & & & \\
-(Mj/kg BK) & 13,892 & 15,272 & 16,535 & 16,015 & 15432 \\
-(Kkal/kg BK) & 3307,69 & 3636,16 & 3973,01 & 3813,19 & 3674,28 \\
ME(Kkal/kg BK) & 2123,13 & 2848,33 & 3750,37 & 3302,04 & 2960,72 \\
\hline Keterangan: Hasil analisis Laboratorium Kimia Pakan, Fakultas Peternakan Undana \\
(2019).
\end{tabular}

\subsection{Variabel Penelitian}

Pemeriksaan profil hematologi yang meliputi jumlah leukosit dan eritrosit menggunakan alat hematology auto analyser. Pemeriksaan morfologi darah dilakukan dengan menggunakan metode ulas darah. Tahapan metode ulas darah diawali dengan pembuatan sediaan preparat ulas darah yang dilakukan di atas gelas objek yang telah dibersihkan dengan alkoholsehingga bebas lemak dan kotoran. Selanjutnya, darah yang telah disiapkan diteteskan ke atas gelas objek, setelah itu ditempelkan ujung gelasobjek yang lain dengan membentuk sudut kurang lebih $45^{\circ}$. Gelas objek kemudian didorong dengan kecepatan konstan sehingga didapatkan ulasan yang cukup tipis.

Setelah itu, ulasan dikeringkan di udara selama beberapa menit, lalu dilakukan fiksasi ulasan dalam methanol selama 5-10 menit. Ulasan kemudian dicelupkan ke dalam pewarna giemsa $10 \%$ selama kurang lebih 10 menit. Setelah itu, ulasan diangkat dan zat warna yang berlebihan dibersihkan dengan menggunakan air yang mengalir sampai air bilasan tidak membawa warna giemsa. Ulasan kemudian dikeringkan dengan cara diangin-anginkan hingga kering dan disimpan pada kotak preparat untuk dilakukan pemeriksaan menggunakan mikroskop (Harvey, 2012).

Jumlah leukosit dapat dikoreksi dengan rumus:

Jumlah leukosit $=$ Sel yang terhitung $x \frac{100}{100+\% \text { Eritrosit yang berint } i}$

Jumlah eritrosit dapat dikoreksi dengan rumus:

Jumlah eritrosit per $\mathrm{mm}^{3}=$ Sel-sel yang terhitung x $10(0,1 \mathrm{~mm}$ ke dalam Haemocytometer) x $5\left(1 / 5\right.$ dari $\left.1 \mathrm{~mm}^{3}\right)$ x $200(1: 200)$

\subsection{Analisis Data}

Data yang diperoleh kemudian ditabulasi dan dianalisis mengikuti prosedur Analysis of Variance (ANOVA) sesuai prosedur rancangan acak lengkap (RAL) menggunakan SPSS versi 19.0.

\section{Hasil dan Pembahasan}

\subsection{Pengaruh Perlakuan Terhadap Kandungan Eritrosit Ternak Sapi} Bali Jantan Percobaan

Sel darah merah terdiri dari 60-70\% air $\left(\mathrm{H}_{2} \mathrm{O}\right), 28-35 \%$ hemoglobin $(\mathrm{Hb})$, matriks organik, dan membran sel non-elastik yang fleksibel (merupakan bentuk khusus atau bikonkaf) (Salasia dan Hariono, 2010). Menurut Sonjaya (2012), pembentukan sel darah merah terjadi di sumsum tulang merah. Pada fetus, eritrosit dibentuk juga di dalam hati dan limfa. Eritropoiesis merupakan suatu proses yang kontinu dan sebanding dengan tingkat perusakan sel darah merah. Eritropoiesis diatur oleh mekanisme umpan balik dimana prosesnya dihambat oleh peningkatan level sel darah merah yang bersirkulasi dan dirangsang oleh anemia. Hal tersebut menyebabkan terjadinya peningkatan pada sel darah merah yang fungsi utamanya adalah sebagai pengangkut oksigen ke seluruh tubuh. Sesuai dengan Rachied et al. (2014)yang menyatakkan bahwa profil darah dapat berubah karena stres, peningkatan jumlah sel darah merah bertujuan untuk memasok lebih banyak oksigen untuk sel-sel tubuh, dimana sel darah merah merupakan cerminan dari faktor gizi atau paparan stres kronis, serta dapat dipengaruhi oleh berbagai mekanisme homeostatis dalam tubuh. Hasil analisis laboratorium terhadap kandungan eritrosit ternak Sapi Bali jantan yang diberikan pakan komplit dengan level PK yang berbeda dapat di lihat pada Tabel 2.

Hasil penelitian pada Tabel 2 memperlihatkan bahwa kandungan eritrosit ternak sapi bali jantan yang diberi pakan komplit dengan level PK berbeda; tertinggi terdapat pada perlakuan $\mathrm{T}_{1}$ yaitu sebesar $11,0810^{6} / \mu 1$ diikuti $\mathrm{T}_{3}$ sebesar $10,9910^{6} / \mu \mathrm{I}$, dan yang terendah pada perlakuan $\mathrm{T}_{2}$ sebesar10,30 $10^{6} / \mu \mathrm{I}$. Hasil analisis statistik menunjukkan bahwa kandungan eritrosit pada ternak sapi bali jantan yang diberi pakan komplit dengan level PK berbeda berpengaruh tidak nyata $(P<0,05)$. Kandungan eritrosit tiap sapi bali jantan pada masing-masing perlakuan dalam penelitian ini masih berada dalam kisaran normal. Menurut Siswanto (2011), jumlah eritrosit sapi bali adalah $5,2 \times 10^{6} \mu$, sementara itu Roland et al., (2014) melaporkan kisaran normal total eritrosit sapi adalah 4,9$10 \times 10^{6} \mu 1$. Total eritrosit yang diperoleh pada penelitian ini lebih tinggi dibandingkan dengan hasil penelitian Adam et al. (2015) yang melaporkan bahwa rataan total eritrosit sapi bali $4,89 \pm 0,53 \times 10^{6} \mu 1$. Hal ini didukung oleh Weiss dan Wardrop (2010) yang menyatakan bahwa peningkatan produksi eritrosit dapat disebabkan karena adanya hipoksia jaringan. Tubuh berusaha memenuhi jumlah oksigen yang dibutuhkan dengan menambah jumlah eritrosit sehingga dapat mengangkut lebih banyak oksigen. Pada keadaan ini, ginjal meningkatkan pelepasan eritropoeitin untuk merangsang produksi eritrosit sebagai respon terhadap hipoksia pada jaringan tubuh.

Tabel 2. Kandungan Eritrosit $\left(10^{6} / \mu 1\right)$ ternak sapi bali jantan percobaan dengan pemberian pakan komplit pada level PK yang berbeda.

\begin{tabular}{cccccc}
\hline Perlakuan & \multicolumn{4}{c}{ Ulangan } & Rataan \\
\cline { 2 - 5 } & 1 & 2 & 3 & 4 & \\
\hline T1 & 10,94 & 10,05 & 12,21 & 11,13 & 11,08 \\
T2 & 10,77 & 9,65 & 10,79 & 9,99 & 10,30 \\
T3 & 11,27 & 12,15 & 10,91 & 9,61 & 10,99 \\
Rataan & 10,99 & 10,62 & 11,30 & 10,24 & \\
\hline
\end{tabular}

Perbedaan hasil penelitian dengan penelitian Adam et al. (2015) tersebut diduga lebih dipengaruhi oleh perbedaan pakan yang diujicobakan. Faktor pakan terutama konsumsi energi sangat menentukan tinggi rendahnya kandungan eritrosit. Dalam laporan-laporan di atas, kandungan eritrosit hasil penelitian Adam et al. (2015) lebih rendah karena hanya menggunakan hijauan $100 \%$, tanpa konsentrat dalam pakan sehingga berdampak pula pada rendahnya karbohidrat mudah tercerna yang dikonsumsi ternak. Konsentrat merupakan sumber energi yang mudah tercerna, sehingga produksi asam propionat yang merupakan prekursor eritrosit akan lebih tinggi. Apabila pakan yang diberikan telah sesuai kebutuhan, akan menghasilkan kandungan metabolik yang normal; namun apabila pakan yang diberikan kurang, maka nilai metabolik darah akan rendah (Ogata, 2010).

Pakan komplit adalah ransum berimbang yang telah lengkap untuk memenuhi kebutuhan nutrisi ternak; baik untuk pertumbuhan, perawatan jaringan, maupun produksi (Teguh, 2012). Semua bahan pakan tersebut; baik pakan kasar maupun konsentrat, dicampur secara homogen menjadi satu. Pada pemeliharaan ternak, protein yang diperoleh ternak akan berdampak pada peningkatan kandungan eritrosit, dimana masing-masing komponen darah tersebut akan berdampak terhadap peningkatan produktivitas ternak (Mide, 2011). Pemanfaatan pakan ternak sapi bali dapat dilihat dari penyerapan nutrisi pakan yang dikonsumsi. Pakan yang dikonsumsi akan dicerna dan didegradasi dalam bentuk nutrien yang kemudian diserap ke dalam darah untuk dialirkan ke seluruh tubuh dengan tujuan mempertahankan keutuhan fungsi organ tubuh Faktor nutrisi berpengaruh terhadap total eritrosit sapi. Semakin tercukupi nutrisi dalam pakan akan menunjukkan total eritrosit yang normal pada darah sapi (Adam et al., 2015).

Pada ternak ruminansia dapat terjadi gangguan pertumbuhan dan perkembangan eritrosit bila terjadi defisiensi vitamin E, B12, B6, besi, dan asam folat. Misalnya penyakit anemia terjadi apabila jumlah sel-sel darah merah atau jumlah hemoglobin berkurang jauh di bawah keadaan normal. Anemia dapat terjadi karena pembekuan darah yang kurang memadai karena gizi yang tidak baik, termasuk adanya defisiensi zat besi, vitamin, dan asarnasam amino di dalam makanan. Anemia juga dapat disebabkan oleh hilangnya darah karena pendarahan dari luka, karena parasit seperti cacing perut, atau karena sel-sel darah merah tidak berhasil menjadi masak secara normal (Frandson, 1993).

\subsection{Pengaruh Perlakuan Terhadap Kandungan Leukosit Ternak Sapi \\ Bali Jantan Percobaan}

Leukosit adalah komponen aktif sistem pertahanan tubuh yang dibentuk sebagian di dalam sumsum tulang dan sebagian lagi di dalam organ limfoid seperti timus, bursa, dan limfa (Sugiharto, 2014). Menurut Soeharsono (2010), kesehatan fisik ternak dapat diukur melalui jumlah leukosit yang dihasilkan, dimana peningkatan jumlah leukosit menandakan adanya peningkatan kemampuan pertahanan tubuh. Penurunan jumlah leukosit juga dapat diasumsikan bahwa tidak adanya infeksi atau gangguan bakteri patogen yang menyerang tubuh. Rataan kandungan leukosit Sapi Bali jantan yang diberikan complete feed yang mengandung protein kasar pada tingkat berbeda dapat dilihat pada Tabel 3 .

Hasil penelitian pada Tabel 3 memperlihatkan bahwa kandungan leukosit tertinggi terdapat pada perlakuan T2 yaitu sebesar 11,59 103/uI, diikuti T1 sebesar 10,51 $10^{3} / \mu \mathrm{I}$, dan yang terendah pada perlakuan T3 sebesar 10,48 $10^{3} / \mu$ I. Hasil analisis statistik menunjukkan bahwa kandungan leukosit relatif sama pada ternak sapi jantan yang diberi pakan komplit dengan level PK yang berbeda dimana nilai total leukosit pada perlakuan T1, T2, dan T3 berada dalam kisaran normal. Menurut Dharmawan (2002), nilai normal sapi berkisar antara $4 \times 10^{3} \mu 1$ sampai $12 \times 10^{3} \mu$ l. Weiss dan Wardrop (2010) menyatakan nilai total leukosit normal sapi adalah 5,1-13,3 x $10^{3} / \mu 1$. Total leukosit yang diperoleh pada penelitian ini lebih tinggi dibandingkan dengan hasil penelitian hematologi sapi perah laktasi yang dilaporkan oleh Suprayogi et al. (2017). Hal ini diduga karena yang diberi pakan dengan kandungan protein dan energi berbeda, dapat meningkatkan total nilai leukosit. Menurut Suprayogi et al. (2017), total leukosit sapi perah laktasi yang dipelihara oleh peternak di Desa Pengalengan, Kabupaten Bandung, Jawa Barat adalah 6,2-10,6x10 ${ }^{3} \mu l$.

Total leukosit yang diperoleh pada penelitian ini lebih tinggi dibandingkan dengan hasil penelitian hematologi sapi perah laktasi; diduga bahwa sapi bali jantan yang digemukkan dengan complete feed pada level PK 
yang berbeda dapat meningkatkan leukosit karena pakan komplit yang diujicobakan telah mengandung protein dan nutrisi yang seimbang. Pakan komplit merupakan pakan yang cukup mengandung nutrien untuk ternak dalam tingkat fisiologis tertentu yang dibentuk dan diberikan sebagai satu-satunya pakan yang mampu memenuhi kebutuhan hidup pokok dan produksi tanpa tambahan substansi lain kecuali air (Mide, 2011). Pemanfaatan pakan ternak sapi bali dapat dilihat dalam penyerapan nutrisi pakan yang ada di dalam darah.

Tabel 3. Kandungan leukosit $\left(10^{3} / \mu 1\right)$ ternak sapi bali jantan percobaan dengan pemberian pakan komplit pada level PK yang berbeda.

\begin{tabular}{cccccc} 
Perlakuan & \multicolumn{4}{c}{ Ulangan } & Rataan \\
\cline { 2 - 5 } & 1 & 2 & 3 & 4 & \\
\hline T1 & 11,85 & 10,73 & 9,13 & 10,32 & 10,51 \\
T2 & 11,1 & 12,06 & 10,86 & 12,35 & 11,59 \\
T3 & 10,85 & 9,25 & 9,86 & 11,95 & 10,48 \\
Rataan & 11,27 & 10,68 & 9,95 & 11,54 & \\
\hline
\end{tabular}

Peningkatan total leukosit merupakan respon fisiologis untuk melindungi tubuh dari serangan mikroorganisme (Wisesa et al., 2012). Peningkatan total leukosit juga dapat terjadi pada hewan yang stres akibat gangguan fisik maupun sebagai induksi dari penyakit, infeksi umum, infeksi lokal, keracunan, tumor, dan trauma. Pada pemeliharaan ternak dengan complete feed pada ternak, protein yang diperoleh ternak akan berdampak pada peningkatan kandungan leukosit, dimana masing-masing komponen darah tersebut akan berdampak terhadap peningkatan produktivitas ternak (Mide, 2011). Pemanfaatan pakan ternak sapi bali dapat dilihat dari penyerapan nutrisi pakan yang dikonsumsi. Pakan yang dikonsumsi akan dicerna dan didegradasi dalam bentuk nutrien yang kemudian diserap ke dalam darah untuk dialirkan ke seluruh tubuh dengan tujuan mempertahankan keutuhan fungsi organ tubuh. Scott dan Elizabeth (2009) menyatakan bahwa sel darah putih melindungi tubuh dari infeksi dengan cara fagositosis, sintesis molekul antibodi, penghancuran bakteri, pembersihan sisa-sisa sel pada jaringan yang mengalami inflamasi, dan melindungi area yang terinfeksi. Sementara itu, Isroli et al. (2009) menyatakan bahwa untuk mengetahui tingkat kekebalan tubuh dapat dilihat dari variabel darah berupa leukosit dan diferensial leukosit secara lengkap. Menurut Soeharsono (2010), kesehatan fisik ternak dapat diukur melalui jumlah leukosit yang dihasilkan.

\section{Simpulan}

Berdasarkan hasil penelitian yang telah dilakukan, dapat disimpulkan bahwa pemberian complete feed dengan level PK 11\%, 13\%, dan $15 \%$ serta energi TDN 72\% memberikan pengaruh yang sama untuk semua perlakuan dan menghasilkan kandungan eritrosit dan leukosit dalam kisaran normal .

\section{Pustaka}

Adam, M. ,T. M. Lubis, B. Abdyad, N. Asmilia, Muttaqien, dan Fakhrurrazi. 2015. Jumlah Eritrosit dan Nilai Hematokrit Sapi Aceh dan Sapi Bali di Kecamatan Leumbah Seulawah Kabupaten Aceh Besar. Jurnal Medika Veterinaria, 9 (2): 115-118.

BPS. 2017. Nusa Tenggara Timur Dalam Angka 2016. Nusa Tenggara Timur: Badan Pusat Statistik.

Dharmawan, N. S. 2002. Pengantar Patologi Klinik Veteriner. Hematologi Klinik. Universitas Udayana. Denpasar: Udayana Press.

Ditjen PKH, 2017. Statistik Peternakan 2017. Direktorat Jenderal Peternakan. Kemtan RI.

Fitria, L dan M. Sarto. 2014. Profil Hematologi Tikus (Rattus norvegicus Berkenhout, 1769) Galur Wistar Jantan dan Betina Umur 4, 6, dan 8 Minggu. Jurnal Ilmiah Biologi (Biogenesis), 2 (2): 94-100.

Frandson, R. D. 1993. Darah dan cairan tubuh lainnya. Anatomi dan Fisiologi Ternak, Edisi ke-4. Gajah Mada University Press.

Harvey, J. W. 2012. A Diagnostic Guide and Color Atlas, An Imprint of Elsevier Inc. Ihedioha, J. I, Ugwuja, J. I, Noel-Uneke, O. A, Udeani.

Isroli., S. Susansi, E. Widiastuti, T. Yudiarti, dan Sugiharto. 2009. Observasi Beberapa Variabel Hematologis Ayam Kedu pada Pemeliharaan Intensif. Seminar Nasional Kebangkitan Peternakan. 20 Mei 2009. Universitas Diponegoro. Semarang.

Junqueira, L. C. 1977. Basic Histology. $8^{\text {nd }}$ Edition. Mc Graw-Hill. New York.

Mide, M. Z, 2011. Penampilan Sapi Bali Jantan Muda yang Diberikan Pakan Komplit. [Skripsi]. Fakultas Peternakan, Universitas Hasanuddin, Makassar.

Nurhannah. 2014. Kecernaan Nutrien Ransum Sapi Bali Dengan Penambahan Sabun Kalsium Minyak Kedelai Secara In Vitro [Skripsi]. Institut Pertanian Bogor.

Ogata, Katsuhiko. 2010. Modern Control Engineering. Fifth Edition. New York: Prentice Hall, Inc.

Rachied, H. G. A., Zaahkouk S. A., El-Zawhry Ei, Elfeky Kh. Sh. 2014. Hematological and Biochemical Parameters in Some Bird and Mammals. Journal of Entomology and Zoology, 2 (2): 153-158.

RolandL., Drillich M., Iwersen M. 2014. Hematology as A Diagnostic Tool In Bovine Medicine. Journal of Veterinary Diagnostic Investigation, 26(5): 592-598.

Salasia, S.I., B. Hariono. 2010. Patologi Klinik Veteriner. Yogyakarta (ID): Samudra Biru.
Siswanto. 2011. Gambaran Sel Darah Merah Sapi Bali (StudiRumahPotong) (The Erytrocyte Profile Of The Female Bali Cattle) [Sloughter House Study]). Buletin Veteriner Udayana. Fakultas Kedokteran Hewan, Univ. Udayana, Denpasar, Bali.

Sugiharto, S. 2014. Role of nutraceuticals in gut health andgrowth performance ofpoultry. J. Saudi Soc. Agric. Sci, 5(12): $99-111$

Suprayogi. A., G. Alaydrussani., A. Y. Ruhyana. 2017. Nilai Hematologi, Denyut Jantung, Frekuensi Respirasi, dan Suhu Tubuh Ternak Sapi Perah Laktasi di Pangalengan. Jurnal Ilmu Pertanian Indonesia (JIPI), 22 (2): 127-132.

Soeharsono. 2010. Fisiologi Ternak (Fenomena dan Nomena Dasar, Fungsi, dan Interaksi Organ Pada Hewan). Widya Padjadjaran. Bandung.

Sonjaya H. 2012. Dasar Fisiologi Ternak. Bogor (ID): PT. Penerbit IPB Press.

Scott, A. S. and Elizabeth F. 2009. Body Structure and Function. Eleventh Edition. United States of America: Delmar.

Tahuk, P. K. and A. A. Dethan. 2010. Performance of bali bull in Greenlot fattening by farmers when rainy season in Timor Island. J. Indonesia Trop. Anim. Agric. 5: 257-261

Teguh, P., 2012. Pembuatan Complete Feed (Pakan Komplit) Untuk Ternak Ruminansia. http://teguhpamuji.wordpress.com/2012/04/24/pembuatan c omplete-feedpakan-komplit-untuk-ternak-ruminansia/. [Diakses pada tanggal 25 Nov 2019].

Wisesa, A. A. N. G., Pemayun, T. G. O., Mahardika, I. G. N. K. 2012. Analisis sekuens D-Loop DNA mitokondria Sapi Bali dan banteng dibandingkan dengan bangsa sapi lain di dunia. Indones Med Vet, 1(2): 281-292. [Indonesian]

Weiss, D and Wardrop K. J. 2010. Schalm's Veterinary Hematology. 6th Ed, Wiley- Blackwell, Philadelphia, PA, USA. 